\title{
New records of millipedes (Diplopoda) from European Russia and Abkhazia, Caucasus
}

\begin{abstract}
Sergei I. Golovatch
Institute for Problems of Ecology and Evolution, Russian Academy of Sciences, Leninsky pr. 33, Moscow 119071 Russia. E-mail: sgolovatch@yandex.ru

ABSTRACT. New faunistic records are provided for 18 millipede species from the European part of Russia or Abkhazia, Caucasus. Among them, a recent, likely anthropochore expansion of the European Craspedosoma rowlinsii Leach, 1815 as far east as the city of Nizhny Novgorod is especially noteworthy.

How to site this article: Golovatch S.I. 2021. New records of millipedes (Diplopoda) from European Russia and Abkhazia, Caucasus // Invert. Zool. Vol.18. No.2. P.80-84. doi: 10.15298/invertzool.18.2.02
\end{abstract}

KEY WORDS: Myriapoda, fauna, distribution.

\section{Новые находки диплопод (Diplopoda) из европейской России и Абхазии (Кавказ)}

\section{С.И. Головач}

\begin{abstract}
Институт проблем экологии и эволюичии РАН, Москва 119071 Pоссия. E-mail: sgolovatch@yandex.ru
\end{abstract}

РЕЗЮМЕ. Представлены новые фаунистические находки 18 видов двупарноногих многоножек в европейской части России и Абхазии (Кавказ). Среди них особенно примечательна недавняя, очевидно, антропохорная экспансия европейского вида Craspedosoma rowlinsii Leach, 1815 на восток до города Нижний Новгород.

Как цитировать эту статью: Golovatch S.I. 2021. New records of millipedes (Diplopoda) from European Russia and Abkhazia, Caucasus // Invert. Zool. Vol.18. No.2. P.80-84. doi: 10.15298/invertzool.18.2.02

КЛЮЧЕВЫЕ СЛОВА: Myriapoda, фауна, распространение.

\section{Introduction}

The millipede fauna of the European part Russia, in contrast to the faunas of Crimea and the Caucasus, has lately received very little attention. Thus, Wytwer et al. (2009) provided ecological and chorological multivariate analyses of millipede assemblages of oak woodlands across the Eastern European Plain, ranging from western Ukraine and Moldova in the west to
Cisuralia in the east. Altogether, 30 species of Diplopoda were revealed, treated, and mapped. In addition, Golovatch \& Matyukhin (2011) have recently provided random faunistic records of a number of diplopod species, largely those found in bird nests across European Russia south to the northern Caucasus. Finally, Evsyukov \& Golovatch (2013), and Zuev (2014) reviewed the millipede faunas of the Rostov-onDon and Stavropol regions, southern Russia, 
respectively, both papers with numerous faunistic records and maps.

\section{Material}

The material underlying the present study was casually collected recently by A.G. Koval (St. Petersburg), O.L. Makarova (Moscow), S.A. Kapralov (Nizhny Novgorod) and I.S. Turbanov (Borok, Yaroslavl Region), and handed to me for treatment.

\section{Taxonomic part}

\author{
Order Polyzoniida \\ Family Hirudisomatidae \\ Hirudisoma roseum (Victor, 1839)
}

MATERIAL. 2 우 (ZMUM), Abkhazia, Gudauta Distr., above Duripsh, Bzyb Mt. Range, $1500 \mathrm{~m}$ a.s.l., forest litter, $\mathrm{N} 42^{\circ} 15^{\prime} 16^{\prime \prime}$, E 40 41'37", 22.VIII.2017, A.G. Koval leg.

REMARK. Subendemic to the Caucasus: Russia, Abkhazia, Georgia, Azerbaijan and northern Turkey (Golovatch et al., 2015, 2021).

Order Glomerida

Family Glomeridae

Hyleoglomeria awchasica (Brandt, 1840)

MATERIAL. 2 juv. (ZMUM), Abkhazia, Gudauta Distr., above Duripsh, Bzyb Mt. Range,

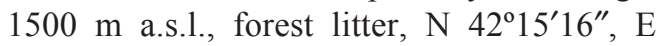
$40^{\circ} 41^{\prime} 37^{\prime \prime}, 22$.VIII.2017, A.G. Koval leg.

REMARK. Endemic to the western Caucasus: Russia, Abkhazia and Georgia (Golovatch, 1989).

\section{Trachysphaera costata (Waga, 1857)}

MATERIAL. 4 ex. (ZMUM), Abkhazia, Gudauta Distr., above Duripsh, Bzyb Mt. Range, $1500 \mathrm{~m}$ a.s.l., forest litter, $\mathrm{N} 42^{\circ} 15^{\prime} 16^{\prime \prime}$, E 4041'37", 22.VIII.2017, A.G. Koval leg.

REMARK. Since the synonymization of several nominal species with $T$. costata, the latter species appears to be widespread in eastern and southeastern Europe, in the Near East,
Anatolia, Crimea and the Caucasus, up to northwestern Iran in the east (Golovatch, 1990, 2008).

Order Julida

Family Blaniulidae

Archiboreoiulus pallidus (Brade-Birks, 1920)

MATERIAL. 1 (ZMUM), Russia, Yaroslavl Region, Tutaev, bank of Volga River, park, sifted litter, 14.X.2020, O.L. Makarova leg.

REMARKS. This species is widespread across Europe, often supporting parthenogenetic popilations. In European Russia, only such populations seem to exist. It also occurs in parklands of Moscow City (S. Golovatch, unpublished).

\section{Nopoiulus kochii (Gervais, 1847)}

MATERIAL. 24 O+, juv. (ZMUM), Russia, Yaroslavl Region, Nekouz Distr., near Borok, inside a Formica truncorum ant nest, 26.III. 2017, I.S. Turbanov, A.S. Sazhnev leg.; 2 우 (ZMUM), Russia, Yaroslavl Region, Tutaev, bank of Volga River, park, sifted litter, 14.X.2020; 1 † (ZMUM), Russia, Nizhny Novgorod Region, Nizhny Novgorod, Shchelokovsky Khutor, complex Quercus forest, sifted litter, 16.X.2020, all O.L. Makarova leg.

REMARK. This is a ubiquitous synanthropic species common both on open terrain and in hothouses across the world, often eutroglophilic (e.g., Golovatch et al., 2021).

Family Julidae

Cylindroiulus pterophylacum Read, 1992

MATERIAL. 1 juv. (ZMUM), Abkhazia, Gudauta Distr., above Duripsh, Bzyb Mt. Range, 1500 m a.s.l., forest litter, N 42 ${ }^{\circ} 15^{\prime} 16^{\prime \prime}, \mathrm{E} 40^{\circ} 41^{\prime}$ 37", 22.VIII.2017, A.G. Koval leg.

REMARK. Endemic to the western and central Caucasus: Russia, Abkhazia and Georgia (Read, 1992).

\section{Cylindroiulus ruber (Lignau, 1903)}

MATERIAL. 2 O $^{\top}, 1$ \% 4 juv. (ZMUM), Abkhazia, Gudauta Distr., above Duripsh, Bzyb 
Mt. Range, $1500 \mathrm{~m}$ a.s.l., forest litter, $\mathrm{N} 42^{\circ} 15^{\prime}$ 16", E 40 41'37", 22.VIII.2017, A.G. Koval leg.

REMARK. Endemic to the northwestern Caucasus: Russia, Abkhazia and Georgia (Read, 1992).

\section{Leptoiulus proximus Nemec, 1896}

MATERIAL. 1 ○', 3 + (ZMUM), Russia, Nizhny Novgorod Region, Nizhny Novgorod, Shchelokovsky Khutor, complex Quercus forest, sifted litter, 16.X.2020, leg. O.L. Makarova.

REMARK. This Northern, Central to Eastern European species is a quite hygrophilous forest-dweller, being very common across European Russia, the Tula Region in the south, Karelia and the Vologda Region in the north, and along the Volga River reaching Tatarstan in the east (Lokshina, 1969; Zalesskaja et al., 1982). In the southeast, it has been recorded from the Penza, Ulyanovsk and Saratov regions, as well as the Republic of Mordovia (Volkova, 2018).

\section{Ommatoiulus sabulosus (Linnaeus, 1758)}

MATERIAL. $1 \bigcirc^{7}$ (ZMUM), Russia, Nizhny Novgorod Region, Arzamas Distr., near Pustyn', shore of Lake Velikoe, in a bark crack of a Populus tremula tree, 15.VII.2007, S.A. Kapralov leg.

REMARK. This very common and widespread pan-European species (Kime, Enghoff, 2017) ranges in Russia from Karelia, the Leningrad, Novgorod, Pskov, Vologda and Kirov regions in the north to the Tula Region in the south, and from the Kaliningrad Region in the west, through Middle Volga regions, to Tatarstan, Bashkortostan and the Chelyabinsk Region (southern Urals) in the east (Lokshina, 1969).

\section{Rossiulus kessleri (Lohmander, 1927)}

MATERIAL. $1+$ (ZMUM), Russia, Nizhny Novgorod Region, Perevoz Distr., 3.5 km SW of Ichalki, Ichalkovsky Bor, Cave Butylka, pitfall trapping, 11.VIII.-21.VIII.2004; $1+22$.VII-
1.VIII.2004; 1 q (ZMUM), same place, Ichalkovsky Bor, Cave Rozhdestvenskaya, entrance part, pitfall trapping, 22.VII.-1.VIII.2004; 1 $\mathrm{O}^{\top}, 2$ 우 (ZMUM), same region, $2.3 \mathrm{~km}$ WSW of Ichalki, Kamennoe natural landmark, quarries, cavern B, pitfall trapping, 05.VII26.VIII.2006; 1 क (ZMUM), same place, Kamennoe natural landmark, quarries, cavern $\mathrm{D}$, pitfall trapping, 15.VI.-5.VII.2006; 1 ㅇ (ZMUM), Nizhny Novgorod Region, Buturlino Distr., near Bornukovo, Cave Bolshaya Bornukovskaya, 10.VIII.2006; 1 † (ZMUM), Nizhny Novgorod Region, Arzamas Distr., near Pustyn', shore of Lake Velikoe, Pinus and Picea forest, litter, 30.VI.2007, all S.A. Kapralov leg.

REMARK. This species is very common and widespread across much of European Russia and eastern Ukraine, ranging from the delta of Severnaya Dvina River (Arkhangelsk) in the north, through the forest, forested steppe and northern steppe belts, to foothills to high mountains of the northern Caucasus (North Ossetia and Dagestan) in the south, and from near Minsk, Belarus in the west to about Ufa, Saratov and Orenburg, Russia in the east (Lokshina, 1969; Kime, Enghoff, 2017). The above records from caves and quarries in central Russia are definitely casual, characteristic of a trogloxene.

Order Polydesmida

Family Polydesmidae

Brachydesmus kalischewskyi (Lignau, 1915)

MATERIAL. 3 O $^{\top} \sigma^{7}$ (ZMUM), Abkhazia, Gudauta Distr., above Duripsh, Bzyb Mt. Range,

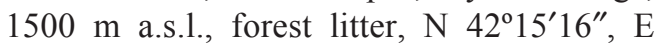
$40^{\circ} 41^{\prime} 37^{\prime \prime}, 22$.VIII.2017, A.G. Koval leg.

REMARK. This polymorphous species is subendemic to the Caucasus: Russia, Abkhazia, Georgia, Armenia, Azerbaijan, northern Turkey and Iran (Golovatch et al., 2016).

\section{?Brachydesmus sp.}

MATERIAL. 4 juv. (ZMUM), Crimea, Sevastopol, Kazachya Bay, in soil and sand among halophytic vegetation on seashore, 10.VII.2017, I.S. Turbanov leg. 
REMARKS. In the absence of adult male material, the above sample could not be identified closer to species. Even the generic identity is uncertain.

\section{Polydesmus abchasius Attems, 1898}

MATERIAL. 1 +, 1 juv. (ZMUM), Abkhazia, Gudauta Distr., above Duripsh, Bzyb Mt. Range, $1500 \mathrm{~m}$ a.s.1., forest litter, N 42 $15^{\prime} 16^{\prime \prime}$, E $40^{\circ} 41^{\prime} 37^{\prime \prime}, 22$.VIII.2017, A.G. Koval leg.

REMARK. Endemic to the western and central Caucasus: Russia, Abkhazia and Georgia (Golovatch et al., 2016).

\section{Polydesmus complanatus (Linnaeus, 1761)}

MATERIAL. $1+$ (ZMUM), Russia, Nizhny Novgorod Region, Ardatov Distr., 2.5 km SW of Balakhonikha, Cave Balakhonikhskaya, 13.VII.2006, S.A. Kapralov leg.

REMARK. This is a very common species widespread across Central, Eastern and Southern Europe, known also from Turkey, introduced to the Nearctic (Kime, Enghoff, 2011). In European Russia, it ranges from about Petrozavodsk and Vologda in the north to Tula in the south, and from the Kaliningrad, Bryansk and Smolensk regions east to Tatarstan and Bashkortostan (Lokshina, 1969).

\section{Polydesmus denticulatus C.L. Koch, 1847}

MATERIAL. $\sigma^{7} \sigma^{7}$,,+ , juv. (ZMUM), Russia, Yaroslavl Region, Uglich, bank of Volga River, park, sifted litter, 13.X.2020; $\sigma^{\top} \sigma^{\top}$, 우, juv. (ZMUM), Russia, Yaroslavl Region, Tutaev, bank of Volga River, park, sifted litter, 14.X.2020; ○ $\sigma^{\top}$, +9 , juv. (ZMUM), Russia, Nizhny Novgorod Region, Nizhny Novgorod, Shchelokovsky Khutor, complex Quercus forest, sifted litter, 16.X.2020; 1 q (ZMUM), Moscow Region, Mytishchi, bank of Yauza River, reed thicket, 19.IV.2021, all O.L. Makarova leg.

REMARK. This species is common throughout Europe, introduced to western Siberia and North America. In European Russia, it is very common in broadleaved forests and parklands south of the taiga belt, often synanthropic (Lokshina, 1969; Zalesskaja et al., 1982; Kime, Enghoff, 2011).

\section{Polydesmus inconstans Latzel, 1884}

MATERIAL. $\sigma^{\Upsilon} \bigcirc^{\Upsilon}$,,+ , juv. (ZMUM), Russia, Yaroslavl Region, Tutaev, bank of Volga River, park, sifted litter, 14.X.2020, O.L. Makarova leg.

REMARK. This species is quite common in parklands and deteriorated forest habitats of central European Russia (Lokshina, 1969; Zalesskaja et al., 1982; Golovatch, Matyukhin, 2011; Kime, Enghoff, 2011), introduced to western Siberia (Nefediev et al., 2016).

Family Paradoxosomatidae Strongylosoma stigmatosum Eichwald, 1830

MATERIAL. $1+$ (ZMUM), Russia, Nizhny Novgorod Region, Arzamas Distr., near Pustyn', shore of Lake Velikoe, wet leaf litter in a karst funnel, 15.VII.2007; $1 \sigma^{7}, 1$ ( 1 (ZMUM), same place, Pinus and Picea forest, litter, 30.VI.2007, all S.A. Kapralov leg.

REMARKS. This species is common and widespread across Eastern Europe, the northern range limit running from about Riga, Latvia eastwards through Velikiye Luki, Tver and Rybinsk to its eastern limit in the Kirov Region. The southern limit runs through Kazan in the east to Kursk in the west and then south through Ukraine(Lokshina, 1969; Kime, Enghoff, 2011).

Order Chordeumatida

Family Craspedosomatidae

Craspedosoma rowlinsii Leach, 1815

MATERIAL. $\sigma^{\top} \bigcirc^{\top}$,,+ , juv. (ZMUM), Russia, Nizhny Novgorod Region, Nizhny Novgorod, Shchelokovsky Khutor, complex Quercus forest, sifted litter, 16.X.2020; 1 juv. (ZMUM), Moscow Region, Mytishchi, bank of Yauza River, reed thicket, 19.IV.2021, all O.L. Makarova leg.

REMARKS. This Western to Central European species seems to have only recently be- 
come established in Moscow City (Golovatch, Matyukhin, 2011). Its expansion over most of city parks in Moscow has since been documented (I. Belyaeva, in litt.), whence it could have colonized the Moscow Region and the city of Nizhny Novgorod, presently the easternmost record.

Acknowledgements. We are most grateful to all collectors who rendered me their material for treatment: Aleksandr G. Koval (St. Petersburg), Olga L. Makarova (Moscow), Sergei A. Kapralov (Nizhny Novgorod) and Ilya S. Turbanov (Borok, Yaroslavl Region). The author was partly supported by the Presidium of the Russian Academy of Sciences, Programme No. 41 "Biodiversity of natural systems and biological resources of Russia".

\section{References}

Evsyukov A.P., Golovatch S.I. 2013. Millipedes from the Rostov-on-Don Region, southern Russia // Arthropoda Selecta. Vol.22. No.3. P.207-215.

Golovatch S.I. 1989. Diplopoda of the Caucasus, 2. Glomeridae, with contributions to the fauna of Turkey // Senckenbergiana biologica. Bd.69. H.4-6. P.421440.

Golovatch S.I. 1990. Diplopoda of the Caucasus, 3. Trachysphaeridae, with contributions to the fauna of Turkey // Senckenbergiana biologica. Bd.70. H.4-6. P.331358.

Golovatch S.I. 2008. On three remarkable millipedes (Diplopoda) from the Crimea, Ukraine // International Journal of Myriapodology. Vol.1. P.97-110.

Golovatch S.I., Matyukhin A.V. 2011. New records of millipedes (Diplopoda), mainly from bird nests, in European Russia // Arthropoda Selecta. Vol.20. No.2. P.115-116.

Golovatch S., Evsyukov A., Reip H.S. 2015. Colobognatha millipedes in the Caucasus (Diplopoda: Polyzoniida, Platydesmida, Siphonocryptida) // Zootaxa. Vol.3972. No.2. P.250-266.
Golovatch S., Evsyukov A., Reip H.S. 2016. The millipede family Polydesmidae in the Caucasus (Diplopoda: Polydesmida) // Zootaxa. Vol.4085. No.1. P.1-51.

Golovatch S.I., Turbanov I.S., Kapralov S.A., Somchenko P.V., Turbanova A.A. 2021. New records of millipedes (Diplopoda) from caves in Crimea and the Caucasus // Invertebrate Zoology. Vol.18. No.2. P.8594.

Kime R.D., Enghoff H. 2011. Atlas of European millipedes (Class Diplopoda). Volume 1. Orders Polyxenida, Glomerida, Platydesmida, Siphonocryptida, Polyzoniida, Callipodida, Polydesmida // Fauna Europaea Evertebrata. No.3. Sofia-Moscow: Pensoft and Leiden: European Invertebrate Survey. 282 pp.

Kime R.D., Enghoff H. 2017. Atlas of European millipedes 2: Order Julida (Class Diplopoda) // European Journal of Taxonomy. Vol.346. P.1-299.

Lokshina I.E. 1969. [Identification book of millipedes Diplopoda of the plain territories of the USSR European part]. Moscow: Nauka. 78 pp. [In Russian]

Nefediev P.S., Kacourek P., Nefedieva J.S. 2016. The first record of Polydesmus inconstans Latzel, 1884 (Diplopoda: Polydesmida: Polydesmidae) in the Asian part of Russia // Arthropoda Selecta. Vol.25. No.1. P.19-21.

Read H.J. 1992. The genus Cylindroiulus Verhoeff 1894 in the faunas of the Caucasus, Turkey and Iran (Myriapoda: Diplopoda: Julidae) // Senckenbergiana biologica. Bd.72. H.4-6. P.373-433.

Volkova J.S. 2018. [Species of myriapods (Myriapoda) new to the fauna of the Lower Volga region] // Izvestiya Saratovskogo universiteta, N.S., seriya Khimiya, Biologiya, Ekologiya. T.18. No.2. P.182184 [in Russian, with English abstract].

Wytwer J., Golovatch S.I., Penev L. 2009. Variation in millipede (Diplopoda) assemblages in oak woodlands of the Eastern European Plain // Soil Organisms. Vol.83. No.3. P.791-813.

Zalesskaja N.T., Titova L.P., Golovatch S.I. 1982. [The myriapod fauna (Myriapoda) of the Moscow Region] // Ghilarov M.S. (ed.). Pochvennye bespozvonochnye Moskovskoi oblasti. Moscow: Nauka. P.179-200 [in Russian].

Zuev R.V. 2014. Preliminary data on the millipedes (Diplopoda) from the Stavropol Territory, northern Caucasus, Russia// Arthropoda Selecta. Vol.23. No.4. P.347-354.

Responsible editor K.G. Mikhailov 